\title{
Survey of Literature: Ted Hughes, Seamus Heaney and Dylan Thomas
}

\author{
Arindam Ghosh* \\ M.A. English, Phd. from Visva-Bharati: Ecocriticism and Post-modern English Poetry.
}

*Corresponding Author: Arindam Ghosh, M.A. English, Phd. from Visva-Bharati: Ecocriticism and Post-modern English Poetry, India

\begin{abstract}
In this article I attempt to carry out a detailed survey regarding the previous critical attention the selected poets, namely Ted Hughes, Seamus Heaney and Dylan Thomas got from various critics concerned with diverse perspectives and argue in favour of the application of ecocritical theoretical postulates to their bulk of poetical works. All of them being modernist poets are writing in the same industrialized, sophisticated and post-war setting, although Dylan Thomas is a little earlier his poetry has its validity in the post-war context. Despite our socio-cultural and psycho-physiological distancing it is curious that all the poets have given considerable prominence to nature in their works. Initially, however, they show that the bond between man and nature is fractured, nature being preeminently hostile threatening man's existence; but ultimately we have the tranquil picture of man either in harmony with nature or seeking refuge and consolation in the lap of nature (both out of love of nature and to avoid drabness and toxicity of industrial existence). Excepting Heaney to some extent none of them excessively glorifies nature; their depiction realistically verges on the basic instincts, raw physicality, mutual interdependence, inherent in nature and display acute concern for the flourishing and well being of non-human life; even Heaney opposed the thought of complete evasion into nature which the Romantics often did or at least contemplated. Although they have their own different approach in their pursuit of nature, for Heaney follows the tradition of Wordsworth and Hardy, and Thomas and Hughes are in the line of Lawrence and Blake, in their poetry the dualism between nature and culture, reason and emotion, culture's corruption and pastoral's impulse to return to nature have become the predominate theme.
\end{abstract}

Keywords: Nature, Culture, Biocentric, Anthropocentric, Pastoral, Myth, Culture, Surrealism

In the present context when all the high theories already ruled the literary sphere the idea of nature is marginalized. Most of literature and criticism in general romanticizes and humanizes nature and consequently forces it to the background, reducing it to a mere setting upon which human action takes place. In addition the modernist world is pervaded by a sense of commercial value, utilitarianism, and post-industrial detachment to the environment - which in turn affects the literature and its criticism as well. Nature is valued only relation to man and finds its burgeoning importance only when it is useful to man. This anthropocentric bias resulted in the general projection of these poets from psychoanalytical and mythological angle: where the nature is not just the external nature of sun, moon and of mountain and birds but nature and its agents are made to perform symbolic functions. Thus, the Crow is an emblem, a demigod - symbolically embodying the existential struggles of a writer (Hirschberg 79); the North is a mythic voice establishing the poet's kinship with the Irish soil and the mythic Irish past (Bloom 10); and Fern Hill complex studies of psychology and synaesthesia (Chamberlain web).

Ted Hughes' (1930-98) earlier reception to the academic world is that of being labeled as 'a nature poet' (Sagar's observations qtd. in Gifford 2009 139) who being enthralled by the instinctual, savage and primordial ferocity of the animal world sought to present a 'pitiless natural world' (Perkins 452) which 'ominously image(s) the essence of man's nature and condition' (ibid.). David Perkins sketchily refers to Hughes's style, theme, influences, features of some of his poetical works and about the 'complicated' (459) artistry. The single most dominant and influential Ted Hughes critic is undoubtedly Keith Sagar who with his multiple volumes (and edited volume) on Ted Hughes namely, Ted Hughes (1972), The Art of Ted Hughes (1978), Ted Hughes (1981), The Achievement of Ted Hughes (1983), The Challenge of Ted Hughes (1994), The Laughter of the Foxes (2000), Ted 
Hughes and Nature: 'Terror and Exultation' (2010) - has almost excavated all the threads of Hughes's poetry and made us acquainted with all the major aspects of Hughes' poetry: about his life; about the psychic split within himself that propelled his poetry making; about the social alienation that he so often explored; and above all about his fierce protest against the capitalist machinery that led to the degradation of the natural world. He is also the joint composer (with Stephen Tabor 1998) of the bibliography on Ted Hughes. Being personally correspondent with and having intimacy Sagar could touch on Hughes' views on religion, royalty, travelling and hunting, education and love and affection with Plath. The Art of Ted Hughes traditionally approaches Hughes' poetic volumes, breaking the central metaphors and focusing on his 'imagination' (4), verging on 'unconscious' (ibid.) that has gone to the making of 'the animal language' (qtd. in 5). Hughes' stylistic stance, development of his poetic theme, meaning of individual poems, their position in the poetic tradition their sources and influences are closely dealt with. The Challenge of Ted Hughes is the product of a conference which encourages innumerable perspectives - ranging from 'the death of poetry' (in the content page), narrative method, 'Romanticism and Existentialism', gender politics, pastoralism and ecology regarding Hughes' poetry. The Laughter of the Foxes much praised for its new critical reading of Hughes, surveys and appreciates Hughes' literary achievement, combining diverse informations, extracts from letters, his mythic consciousness etc. But the volume in reality captures Hughes' poetic essence his 'potentially redemptive vision' (qtd. in Sagar web). Ted Hughes and Nature explores Hughes' relationship with and journey through the changing faces of nature. Hughes although imbibed with western rationality, scientific thought and Christianity, did not fail to see the spiritual unity, the abundance of interrelated life system. Sagar argues that the theme of nature provide the continuum needed for Hughes in his exploration of the relationship between life and poetry. Terry Gifford, an ecocritic and Ted Hughes specialist collaborated with Neil Roberts in Ted Hughes: A Critical Study (1981) to comment on Hughes' language, his love of nature, his knowledge of death and more importantly his fascination with 'elemental powers' (12) and the poetic activity bordering on the theme of 'violence' and 'vitality' (ibid.). Hughes' poetry has been critically treated depending on personal correspondences and original material and beliefs. In Ted Hughes (2009) Gifford besides discussing some of Hughes' works in detail provides us with the distinguishing critical acclaim on Hughes categorized under several themes. The Cambridge Companion to Ted Hughes (2011) edited by Gifford offers comprehensive critical survey regarding the major themes in Hughes's poetry and encourages various theoretical perspectives. Going beyond the close reading of the poems, the volume opens histrio-biographical, socio-ecological, mythic and anthropologist, and feminist literary discourse on Hughes.

Leonard M. Scigaj in the edited volume Critical Essays on Ted Hughes (1992) speculates over Hughes' style and poetical aesthetics, at the sametime covers critical commentary on almost all of his poetical volumes. In the introduction he considers portions of Lupercal in post-imperial light. In his earlier The Poetry of Ted Hughes: Form and Imagination (1986) he closely sticks to the biographic details and publication history treating works upto River. While the 1991 volume Ted Hughes is marked by its insightful assessment of Hughes' poetry from structuralist, formalist, ecological parameters; and also involves spiritual concerns of the poet in the chapter titled - "Aggression and a New Divinity: Wodwo and Crow". The Casebook series Three Contemporary Poets (1990), edited by A. E. Dyson, includes articles which are normally the critical outcome on Hughes during the fifties and sixties. Yet the volume is an aid on the account that it presents Hughes' own views on the major tropes of his poetry, such as: on violence, on symbols, on poetic influence, on philosophy, on shamanism and so on. Stuart Hirschberg explores Hughes' well known fascination for myth and the rootedness of his works in mythology, in the volume Myth in the Poetry of Ted Hughes (1981). Hughes' deep knowledge in anthropology enabled him the mastery over myths, folklore and legends that propelled him to present his poetry under the 'self-adopted masks' (7), namely - 'Shaman', 'Trickster', and 'Scapegoat' (ibid.). Hughes mystically relates the animal world with the mythical and 'rooted his personal feelings in the context of universal archetypes' (9). Thomas West's Ted Hughes (1985) is one of the earliest volumes that introduced us to Hughes' works, capturing 'the drama and the gestures behind the verbal surface' (on title page). A single volume that provides minute and well researched biographic details on Hughes is Elaine Feinstein's Ted Hughes: the Life of a Poet (2001). Paul Bentley's The Poetry of Ted Hughes: Language, Illusion and Beyond (1998) comprehensively studies the development of Hughes' poetic language side by side with the contemporary poets. Ekbert Fass critically studies Hughes, provides valuable background informations, and introduces Hughes 
through the interviews he himself conducted in the volume - Ted Hughes: the Unaccommodated Universe (1980). This often cited book combines Hughes' biographical details with his poetic vision: his creativity, primitivism, language and poetic imagination. Joanny Moulin's recently published edited volume Ted Hughes: Alternative Horizons (2004) involves quite different kind of approaches to Ted Hughes' poetry. The essays as unique in their stance apply psychoanalytical logics, deterministic principles, sublimity and magical elements while reading Hughes' poetry. Moulin indulges himself with Hughes' 'anti-mythic method' (in the content page). Moulin's earlier (ed.) Lire Ted Hughes: New Selected Poems 1957-1994 (1999) also included experimental reading. Ann skea's chief interest lies in Hughes' visionary quest, his poetic and structural methods and innovations and metaphysical symbolism. Her book Ted Hughes: the Poetic Quest (1994) is informative, resourceful and encouraging in the 2005 (online) volume, Skea applies magic, esoteric doctrines and cabbalistic principles within the contours of poetic mode while reading Hughes's Birthday Letters.

With the publication of The Hawk in the Rain (1957) many reviewers and critics were impressed by Hughes' technical agility, his vital poetic mode and much more by his professed distancing from the urban-centrism and over-rationalistic pose of the Movement poets. Robin Skelton, a reviewer of the Manchester Guardian apprehended 'the emergence of a new talent' (Garrard 2009 102); Graham Hough was impressed by the keen 'poetic intelligence' (ibid.). When Lupercal (1960) came into being Hughes' affinity with the animal world becomes obvious: Fredrick Grubb in his book A Vision of Reality (1965) identifies Hughes with instinctuality, entitling a chapter - "Thinking Animal: Ted Hughes" (ibid.). But some critics had already started to attack Hughes on the theme of violence and on his troubled personal life. Wodwo (1967) produced mixed reactions: despite Seamus Heaney's admirations critics like Daniel Hoffman and others could not find the 'healing power' (qtd. in 103) in Hughes' poetic quest and was cynical of his 'non-consolatory nature' (ibid.). Crow (1970) marks the acme of Hughes' poetic career producing inspired reviews from all sections. Charles Fernandez appreciates the 'reformulat(ing) and revitalize(ing)' (104) aspect of Hughes' myth against the failures of western civilization. Neil Roberts [who among the prominent Hughes critics with volumes, such as - Narrative and Voice in Postwar Poetry (1999), Ted Hughes: a Literary Life (2006), Ted Hughes: New Selected Poems (2007) (ed.)], J. M. Newton and others discover 'religious ferocity' (ibid.), 'the poet's direct engagement with the Goddess of complete Being' (105) and 'most enduring and humanly significan(ce)' (ibid.) in Gaudete (1977). The obscure and experimental narrative and mythic mode of Cave Birds (1978) caught the attention of several critics like Scigaj, Hirschberg, Sagar; Gifford in his 2004 volume treats the sequence as embodying post-pastoral characteristics. Remains of Elmet (1979) and Moortwon (1979) rather appealed for their presentation of the landscapes, their lucid language, and Hughes' stylistic innovations. River (1983) propels Edna Longley to find 'the Lawrentian exclamation' (106) in Hughes.

Wolfwatching (1989) assimilates personal elegies with socio-cultural and ecological consciousness. Carol Ann Duffy, John Lucas, Derek Walcott appreciated his 'empathy', 'sharpness', and 'ecology' concern (ibid.). Already acclimatized as one of the most powerful poets of the time, Hughes, amidst his growing influence on British culture and equally pungent attack from the feminist critics, published Birthday Letters (1998) which bought him instant reputation and praises galore from all sections of academic critics. Blake Morrison thought that the poet himself is 'an active protagonist inside the myth - like minotaur in the labyrinth' (109); and Andrew Motion unreservingly called this venture - 'his greatest book' (ibid.). The charges against Hughes are not few: first and foremost his poetry is burdened with studied obscurity, difficulty and deliberate complexity; then he failed to meet the new challenges that his own poetry posed; his portrayal of feminity as 'devouring and fearful' and masculinity as 'isolated aloof' (ibid.) is biased. Yet in the face of destructive society Hughes stands firm as 'the poet-shaman and healer' (ibid.). Now, Hughes' poetry, marked by too often linguistic experimentation and technical innovation, Hughesian language undoubtedly became a matter of conjecture for many critics, keith Sagar speaks of Hughes' words: 'words that live in the same dimension as life at its most severe' (qtd. in 1975 33); adding to that he argues in favour of Hughes' deliberate pouring of himself of rhetoric for 'a simplicity not of retreat or exclusion' (qtd. in Gifford 2009 112). Calvin Benedict applies the expression 'voyeur of violence' (11). Actually many critics thought that in order to highlight the elemental, predatory aspect of nature Hughes improvised his language to 'a rejection of the self-sufficient ego' (Gifford \& Roberts 15) and often 'overdone virility and overdone violence' ((J. M. Newton, qtd. in Gifford 2009 111). Myth is Hughes' medium for connecting his personal self to poetry, poetry to nature and of corresponding contemporary crisis to 
the conflict embedded in the history of the species. In The Art of Ted Hughes, Sagar found that Hughes was much inspired by Robert Grave's The White Goddess. Wodwo, Cave Birds and Gaudete mark the poet's attempt to heal the cultural world to which nature is subjected to and the 'healing process' (119) is 'potentially mythic' (ibid.). In Crow Hughes deconstructed and hence reconstructed Christian myth. Gifford thinks that 'Hughes reached a redemptive vision in the mythic journey of his shamanic trials' (120). Scigaj traces the blending of oriental influences with occidental myths and folklore which aided Hughes to 'transmute pains into vision' (122). Hirschberg explores the mythic patterns in Hughes to find 'a movement that enacts the archetype of the dying and reviving God through mythic patterns of dismemberment of the ego . . ' (124). Nick Bishop is of the opinion that Hughes is using 'collective imagination' (125) for the resolution of the conflict inherent in society, culture and in nature. Hughes' engrossment with myth and nature led him to be quite indifferent (excepting the Laureate poems) towards history and politics; which however, justifies his engagement with radical environmental politics. Many critics ranging from Gifford, Roberts, Craig Robinson pointed out Hughes' serious involvement with ecological concerns: Gifford speaks of his transition from 'nature poet to eco poet' (qtd. in 139); Scigaj discovers Hughes' biocentric vision; Sagar keeps faith in Hughes' ecocentric poetry in transforming our attitude towards the ecosphere in the present context of environmental crisis. ${ }^{1}$

Apart from those mentioned above Hughes' strikingly individual, poignantly radical poetry continues to entice and engross critics even today, which is evident in the large number of still burgeoning volume of books, articles and research works. An attempt to summarize the recent critical output regarding Hughes has been made in the New Case Book (2013), edited by Terry Gifford which includes Keith Sagar's posthumous article. We must mention a number of books that are essential in opening new dimensions for Ted Hughes criticism and are absolutely indispensible in carrying out research on Hughes, such as: Ted Hughes (2009) by Susan Bassnett; John Greening's The poetry of Ted Hughes (2007); Edward Hedley's The Elegies of Ted Hughes (2010); The Epic Poise: a Celebration of Ted Hughes (1999) edited by Nick Gammage; Ariel's Gift: Ted Hughes, Sylvia Plath and the Story of Birth Letters (2000) by Erica Wagner; Sandie Byrne's The Poetry of Ted Hughes: a Reader's Guide to Essential Criticism (2000); Daniel Xerri's Ted Hughes Art of Healing (2010); An Essential Self: Ted Hughes and Sylvia Plath (2011) by Lucas Myers; Ted Hughes: from Cambridge to Collected (2013) edited by Mark Wormald, Neil Roberts and Terry Gifford. The abundance of theses, articles and papers cannot be included into this small space. Certain websites like - that of the Ted Hughes Society (www.thetedhughessociety.org); Earth-Moon (www.tedhughes.info); of Ann Skea (http://ann.skea.com); of Keith Sagar (www.keithsagar.co.uk); of Roy Davids (www.roydavids.com); and so on - provide exclusive update on Ted Hughes studies; they connect us to the Hughes fraternity by providing us informations, news of publications, critical materials, and bibliographical details etc.

Seamus Heaney (1939-2013), often reviewed as a 'bucolic poet' (Perkins 481), intensified the traditionalist approach to poetry by connecting personal past with the national history of Ireland and by providing psychological and moral dimension to pastoralism and juxtaposing harsher images of contemporary world with the unsentimental, malevolent aspects of nature. Harold Bloom finds the deep influence of Robert Frost and Ted Hughes on Heaney. David Perkins draws our attention towards: Heaney's presentation of the 'alien, threatened and threatening nature' (ibid.); his 'symbolist' and alternative mode of psychological realism; feelings of guilt, turbulence of emotion in the context of religio-political violence; attempt of transcending personal anguish through the contemplation of Ireland as 'pilgrimage' (485). Despite Robert Lowell considering him 'the most important Irish poet since Yeats' (wiki web), and even despite Swedish Academy's fascination for his 'lyrical beauty and ethical depth' (PF web), one might feel surprise at the comparative scarcity of critical output on Heaney. Yet some illuminating critical works help us to apprehend the poetic strategies, images and symbols and metaphors, motives, socio-political framework, linguistic and technical avant-gardism, the trope of place in the formulation of personal identity and in the development of nationalistic politics. Blake Morrison is probably one of the earliest to conduct any

\footnotetext{
${ }^{1}$ T. Gifford, 2009 101-148. Gifford in the following volume has a separate chapter on Ted Hughes' academic reception entitled as "Criticism". For the minute details about the critical reception of each of Hughes' volume I blindly stuck to the volume. However, Gifford's survey involves unprecedented examination of the opinion of several almost all the critics on Hughes' : 'Reputations', 'Language', 'Myth', 'Laureateship, History and Politics', 'Hughes and Plath' and 'Ecology'.
} 
serious study on Heaney; his Seamus Heaney (1982) skillfully captures the poet's biographical details and brief backgrounds attempts to reach out to his sources, situates him to the Anglo-Irish tradition and searches for explanation of his poetry's intricate deep connection with the contemporary political turmoil of Northern Ireland. The book clearly depicts Heaney 'breaking with rationalistic mode' (Blakemorrison web) and defines his perspectives of poetry making. Toni Curtis edited the volume The Art of Seamus Heaney (1982) which attempt to arrange Heaney's progress and development in his poetic career - both chronologically and thematically. Curtis introduces Heaney; speaks of his fascination for Hardy, Yeats; assembles multiple critical approaches on Heaney. The book with its illustrations on the origin, influences, development, theme and technique of Heaney's poems initiates a 'practical criticism' (Persee web): Hobsbaum's article gives an overview regarding Heaney's handling of the Irish verse form, his authentic themes and poetic craftsmanship. Prof. Hardy's concern lies mainly with Heaney's language - studying image, metaphors, allegory etc., yet she offers insightful commentary on Heaney's treatment of myth - defamiliarising personal experiences and 'congenial concerns, of large tragic myths' (ibid.).

Harold Bloom's edited versions Modern Critical Views: Seamus Heaney (1986) and Seamus Heaney: Comprehensive Research and Study Guide (2003): accumulate critical views on Heaney from some of the most prominent Heaney critics, such as Blake Morrison, Richard Ellmann, Terence Brown, Helen Vendler and others who comment on the poet's biography, thematic and structural elements; the precision and open endedness introduce readers to indulge in various threads of Heaney's poetry; and capture a mature poet rooted in his Irish experience. Critical stances include concerns with biographic elements; 'dismantling of heroic myth' (in the content page 2003); connection of agrarian field works with poetry making; the impact of violence, place itself, identity crisis, suffering and trauma on Heaney. Daniel Tobin and S. C. Greer speaks of the 'transcendent(al) aspects of Heaney's poetry; while Helen Vendler explore Heaney's 'widened gaze' (ibid.). Henry Hart in the introduction to Seamus Heaney: Poet of Contrary Progressions argues that Heaney is generally considered as - "a pastoralist whose homely portraits of rural Irish life attracts both curiosity and sympathy but are ultimately sentimental" (1); some others discover in him 'romantic poetry of transcendence' (2) or 'principled social engagement' (ibid.). Hart also commandingly comments on - Heaney's 'pastoral and anti-pastoral attitudes', his meditative qualities, and his use of 'history, myth or apocalypse' (content page) etc. One of the most celebrated critical works on Heaney, Michael Parker's Seamus Heaney: the Making of a Poet (1993) provides us with background informations, his Ulster Catholicism, personal relationships, possible sources of his poems, including drafts and photographs. The initial chapter provides us with his childhood influences that so often went to the making of his symbols, images and allusions. Regarding Station Island he observes Heaney's struggle for selfidentity, the attempt at reconnecting to 'the watery land which bore him' (99), the shadow of civil war, and the progress towards 'stillness, longing for a Wordsworthian tranquility and assurance of continuities' (ibid.).

Michael Allen is the editor of the Seamus Heaney: New Casebook (1997) which introduces various theoretical approaches to Heaney's poetry. The book, however, has a suggestion that often Heaney's own critical stances have provided parameters for reading his poetry. Critical commentary includes: Edna Longley's article 'Artful Voyeur' (content page); modernity and representational elements; dispossession and the formulation of poetic identity; feminist elements; postmodern aspects and the representation of the landscape; and so on. Eamonn Hughes' article takes its conceptual elements from formalism and postmodernism in approaching Heaney's North. Sidney Burris, author of The Poetry of Resistance: Seamus Heaney and the Pastoral Tradition (1990) explores the weight of social injustices and turbulence over the poet and examines the social purposes and responsibilities of his poetry. In the time of social problems and conflicts of nationhood the poet's response was through the development of his poetic craft which focused on bucolic, pastoral past for resolving the constricting dilemmas. Burris argues that pastoral poetry, in Heaney's craft is essentially reformed, modernized "refurbishing its traditional capacity to proffer trenchant social and cultural criticism while honouring the aesthetic demands of art" (The poetry of Resistance web). The Poetry of Seamus Heaney: a Critical Study (1998) by Neil Corcoran offers detailed account of some of his most famous poetic volumes. Besides the close reading of the volumes it also includes Heaney's own activities in literary criticism which is preoccupied with the act of 'listening . . . to the poem's sounds' (209). Elmer Kennedy-Andrews edited The Poetry of Seamus Heaney (1998) [also edited Seamus Heaney: a 
collection of Critical Essay (2003)] which enables us to grab the real critical reception Heaney's poetry got and therefore maps his place within the canon of English poetry. Besides it identifies the issues most relevant regarding Heaney's poetry, such as, 'place', 'identity', 'language', 'politics', 'gender', 'colonialism', 'nationalism', connection with the 'earth' (content page) and accumulates critical attention on them ranging from: cultural and canon theory, deconstructionist analysis, poetry in the light of 'Jungian individualism', 'anti-revivalist' strategies, mythic interpretation of the poetry of Seamus Heaney (ibid.) etc. Bernard O' Donoghue authored Seamus Heaney and the Language of Poetry (1998) which solely concerns itself with Heaney's language so that to reveal his theory of poetry; in the more recent edited volume, The Cambridge Introduction to Seamus Heaney (2008), O' Donoghue gives perhaps the most detailed, comprehensive and inclusive overview of Heaney's poetry, combining and modifying theoretical approaches, critical receptions and analysis of poetical voice. The volume attempts to establish the authenticity of Heaney as a world poet.

Death of a Naturalist (1966) his first poetic volume immediately achieves critical favour for linguistic brilliance, and for enlivening the country experience in Country Derry. Many influential critics like C. B. Cox, Peter Marsh, Elizabeth Jennings, and Christopher Ricks appreciated Heaney's artistic presentation of places, objects and memories and his evocation of the Derry childhood. C. B. Cox argues that the poems offer the 'soil-reck of Ireland' (qtd. in O' Donoghue 3). The automatic acclaim continues with the Door into the Dark (1969) which also confirms Heaney's affinity to the bucolic tradition: in Rick's opinion he became 'the poet of muddy-booted blackberry-picking' (Andrews 12); similarly Douglas Dunn commented that the poems were 'loud with the slap of the spade and sour with the stink of turned earth' (qtd. in O' Donoghue 3). Wintering Out (1972) compelled Michael McLaverty to apply Hopkin's phrase to Heaney: 'description is revelation' (ibid.). Although the volume incorporated a political text, Heaney's descriptive qualities, childhood references, characteristic poetic intelligence can be discernible. Robert Buttel's Seamus Heaney (1975), first monograph on the poet enthusiastically captured the 'naturalist' (ibid.) poet with cultural and political preoccupations. The publication of North (1975) produced raucous and tensions not only because of its sustained political interest, but also it takes Heaney's poetry from the narrative, bucolic towards the anti-pastoral. Heaney's catholic upbringing left undeniable marks on his poetic volumes and O' Brien charged Heaney for evoking 'unbalanced' (4) sentimentality towards the Catholic suffering.

Christopher Ricks quoted Heaney's lines from the Field Work (1979) - 'the end of art is peace' (Qtd. in Andrews 13) - and hailed Heaney as the poet of 'civilization', a 'source of comfort' during the time of emergency and crisis (ibid.). The volume reenters 'a new bucolics' ( $O$ ' Donoghue 6) despite its under-lied sense of guilt and turbulence and violence; here Heaney arouses human sympathy, gives ingenuous social details and shouts for artistic freedom. Alvarez, the English critic was impressed by Heaney's 'fine way with the language' (qtd. in Andrews 18). Blake Morrison found in Heaney's poetry 'a concern for poetry itself' (23), but in his volumes like Sweeney Astray (1983) and Station Island (19840 the poet returns to his concern with society, guilt and responsibility. Some critics like Michael Allen, Denis Donoghue at this stage considered Heaney as puzzled, 'unanchored artist' (O' Donoghue 7) but Heaney's 'Dantesque' (ibid.) power of narrative salvages him. Sweeney Astray is the Heaney's version of the Irish myth, while Barbara Hardy discovers in Station Island, 'a new structure for complex experiences of childhood and adolescent recall, an ironic religious sense, and a deep political unease' (Bloom 83). Michael Molino, however, finds that in the volume Heaney is bending on doing justice to 'a number of voices' (87) who suffered victimization. The Haw Lantern (1997) is imbued with 'a typically post-modern self-consciousness' (Andrews 25) in which he explores his dubious relationship with 'the linguistic, discursive and ideological systems' (24); John Carey's concern is on 'objects and textures' and he finds the poet 'quest(ing) for silence' (qtd. in ibid.). Bernard O' Donoghue thinks that Seeing Things (1991) is based on 'the celebration of the marvelous by invoking artistic license' (11). Helen Vendler and others are of the opinion that it is also obviously motivated by Dante's Inferno and consider the volume as 'the representation of (the) visionary perspective' (ibid.) of the poet. The Spirit Level (1996) is endowed with considerable amount of pessimism; Nicholas Jenkins is impressed by 'a greater subtlety and fluidity' (Andrews 162) - 'give and take' (qtd, in ibid.) activity; others concentrate on the poet's insight of a 'savage' (164) peace, his rendering of and 'groping after half-sensed, airy realities, mysterious states of mind and the things of the spirit' (ibid.). O' Donoghue again conceives of The Electric Light (2001) as 'pastoral genre' (12), perceived by 'grim politics' (ibid.). The volume full of allusion from Homer or Virgil mixes - 
memory, pastoral ad elegy; according to an American critic the poetic volume is 'a Janus-faced book, elegiac' (PF web). ${ }^{2}$ The 2006 volume District and Circle is pervaded by 'chthonic and the transition to the afterlife' (O" Donoghue 12-3). The poet's such response must have been due to the imperial domination and oppressive activities. Another American critic Bard Leithauser commented that the volume bears the mark of Heaney with its 'authenticity and believability and plainspoken(ness)' (PF web).

Heaney's most recent published poetical work Human Chain (2010) crowned with many prestigious awards, is about 'inheritance' (the Guardian web); chain meaning 'man hand(ing) misery to man' (ibid.). Kate Kellaway wrote in the review for The Observer that the 'collection muses upon heredity and absent friends with restrained and rich imagery' (ibid.). Colm Toibin wrote for The Guardian that the volume 'brilliantly enacts the struggle between memory and loss' (ibid.). Blake Morrison and Andrew Motion in the Introduction to the Penguin Book of Contemporary British Poetry (1982) observed that Heaney does not represent anything innovatively new, but he is the key figure in 'a movement away from the Movement' (Andrews 24): the immensely popular - place poems, bog poems, Glanmore sonnets represent the primacy of the imagination of the 'new poet' (qtd. in ibid.). The theme of Heaney's prose collection - The Redress of Poetry (1995) - is that it talks about selfjustification, in balancing artistic license and moral responsibility. Finders and Keepers: Selected Prose, 1971-2001 (2002) assesses the value and social purpose of poetry that constantly pricked Heaney: John Carey thinks that it embodies 'Heaney's thirty year struggle with the demon of doubt' (PF web).

That Heaney is critically no less privileged, and that he has the rightful fame of being - 'probably the best known poet in the world' (The Independent 2013) (wiki web) are justified by the ever growing critical interest and still burgeoning critical volumes on his poetry. Despite the brief account I have given above some other critical works not bound to provide judgment but for the purpose of elucidation bring out remarkable threads and direction in reading Heaney and are valueless for perceiving the poet's works. To mention a few: Thomas C. Forster's Seamus Heaney (1989), Critical Essays on Seamus Heaney (1995), edited by Robert F. Garratt, Seamus Heaney (1998) authored by Helen Vendler, Eugene O" Brien's two volumes Seamus Heaney: Creating Ireland of the Mind (2002) and Seamus Heaney and the Place of Writing (2002), Rand Brandes and Michael J. Durkan's attempt Seamus Heaney: a Bibliography (2008), Danniss O' Driscoll's Stepping Stones: Interviews with Seamus Heaney (2008), Seamus Heaney (Writers and their Work) (3 $3^{\text {rd }}$ ed.) (2010) by Andrew Murphy, "Mirror upto Nature": Fourth Seamus Heaney Lectures (2010) edited by Patrick Burke, Floyd Collins' Seamus Heaney: the Crisis of Identity (2003), Michael R. Molino's Questioning Tradition, Language and Myth: the Poetry of Seamus Heaney (1994), In Gratitude for all the Gifts: Seamus Heaney and Eastern Europe (2012) by Magdalena Kay - are fascinating and essential as Heaney criticism. Numerous journals and periodicals and certain websites like: www.poetryfoundation.org, www.nnetb.com, www.nobleprize.org, http://en.wkipedia.org are very much of help in providing latest information, publication details, select bibliographies etc; www.jstor.org offers some critical articles and Google Books (http://books.google.co.in) allows portion of books of convenience.

Dylan Thomas (1914-53) in spite of his own fierce complaint is being dubbed as a 'Welsh poet' (wiki. Web) who led to the neo-romantic trend in the twentieth century through reviving Romantic and Transcendentalist ideologies in the face of a War-trodden pessimistic world. He dexterously combines tenets of modernism and romanticism, symbolism with surrealism, hovering Biblical myth and folklore with Freudian psychoanalysis. David Perkins impressed by this 'rebellious genius' (176) finds his poetry as somewhat challenging the dominant mode of poetry making in the 1930s, marked by: his fascination for 'hynotic incantation' (175) and modification of Hopkinsian sprung rhythm; deliberately abstruse and 'obscure' (ibid.) style; abundance of natural images verging on pantheism; obsession with death and Biblical images; metaphysical symbolism etc. Thomas's rowdy lifestyle, his precocity did not seriously affect his popularity, but hampered the flow of his imaginative ability resulting in the insignificance of the amount of poetic volumes; which in turn explains the natural

\footnotetext{
${ }^{2}$ Regarding the details of Heaney criticism I am enlightened by the volumes of O'Donoghue and Elmer Andrews and portions of it I took from the Poetry Foundation Website. I rigidly believed the authenticity of the informations and am indebted to them for their elucidating purposes.
} 
dearth of critical output, undue to the merit of this protégée. John Ackerman claims the fame of carrying out extensive research on Dylan Thomas with his three volumes: A Dylan Thomas Companion: Life, Poetry and Prose (1991), Dylan Thomas: His Life and Work (3 ${ }^{\text {rd }}$ ed.) (1996), and Welsh Dylan (1998). A Dylan Thomas Companion is divided into three sections: the 'Life' section captures the setting upon which Thomas grew up - the Swansea, and Wales background provided the first impetus of his poetry, then he moved onto London and finally to Laugharne and America; after that the author scrutinizes his early notebook and manuscript verse in order to distinguish the emergence of Thomas's new poetic voice; in the final section Thomas' development as a prose writer has been traced through examining his prose works ranging from films, radio broadcast, to letters and stories and so on. The book tries to find the sources of some of his works both literary and biographical. The intense focus of this book lies on the poet's presentation of the natural world. The next volume also runs in the same line, examining biographical details, poetical influences, family roots, radical politics, Welsh nonconformity that have gone to the development of the poet. The book links Thomas's poetry unavoidably to the Welsh background, which is the major theme of welsh Dylan, the volume that firmly establishes Thomas as 'a Welshman' (Ackerman 4).

Alan Bold edited the volume Dylan Thomas: Craft or Sullen Art (1990) which provides us critical examinations on Thomas' poetry and other works which are of immense help in decoding his poetic craft. Walford Davies produced Dylan Thomas: New Critical Essays (ed.) (1972), Dylan Thomas: Open Guide to Literature Series (1986) and Dylan Thomas: Writers of Wales Series (1990). The 1972 volume assesses the achievement of Dylan Thomas against the Welsh background. The book considers Thomas as one of the most accomplished poet of the twentieth century while excavating the cultural impact that underlies the poetic subtext. The 1990 volume critically appreciates the poetic faculty of the poet and analyzes his poetry in the light of surrealism, national-cultural definitions, against the contemporary poetic trends, especially in comparison with the Movement Poets. The book's main critical stance is overtly textual analysis. Davies is also the co-editor of Thomas's Collected Poems 1934-53 (1989). C. B. Cox edited Dylan Thomas: a Collection of Critical Essay (1966) which, subtitled - "Twentieth Century Views" offers close survey of Thomas's poetic style and features. The book is one of the earliest to offer a kind of practical criticism on Thomas's poetry. John Goodby and Chris Wigginton jointly edited the New Case Book series - Dylan Thomas: Contemporary Critical Essays (2001). The volume combines close study of poems along with theoretical approaches to Thomas's poems. S. Crehan surveys his pervasive concern with 'Time' (content page); Katie Gramich observes the celebration of feminity in Dylan Thomas' poems; Wigginton's own article explores 'Gothic Modernism and Surrealism' in Dylan Thomas' verse; Walford Davies' article is concerned with his narrative technique and language. Barbara Hardy, credited with two volumes on Thomas - Dylan Thomas' Poetic Language: the Stream that is Flowing Both Ways 1987) and Dylan Thomas: an Original Language (2000) is evidently interested in his lingual experimentation. The latter volume throws light of Thomas's powerful articulation, depiction of the inner self and 'imaginative recreation of forms and language' (UGA Press web). Hardy compares and contrasts him with other modernist artists, revealing his themes, subject matter, regional identity and his response to the landscape and the natural world. To Hardy, Dylan Thomas is a 'language-changer' (qtd. in ibid.) and his poetry is 'artistic(ally) celebration of greenness - literal, metaphorical and political' (ibid.). David Holbrook, another critic on Thomas infamously authored Llareggub Revisited: Dylan Thomas and the State of Modern Poetry (1962) and Dylan Thomas: the Code of Night (1972); the 1972 volume depicts both the struggle of 'the schizoid individual' (25) and the profound dilemmas of the creative artist. The eponymously titled chapter "The Code of Night" offers 'crude psychoanalytical' (Goodby \& Wigginton 2) studies of Thomas' poetry.

Ralph Maud's venture into Dylan Thomas with Entrances to Dylan Thomas' Poetry (1963), Dylan Thomas in Print: a Bibliographical History (1970) and Where Have the Old Words Got Me (2003) never fails to appreciate the immense popularity of the poet. The last volume provides critical analysis of some of his poems, linking poetry making with biographical details. In the "Introduction" he traces the 'strict chronological order' (xv) of the volumes with the development of poet's career. Paul Ferris in 1977 produced Dylan Thomas: a Biography capturing the enchanting and attractive life of this lyrical genius which evokes both 'the extremes of admiration and hostility' (Goodreads web). The incongruent mixture of talent, audacity, alcoholism and reflection on despair make and mar Thomas' vocation as a poet. Andrew Lycett's much latter work Dylan Thomas: a New Life (2003) also sketches the impartial biography of the self-styled 'Rimbaud of Cwmdonkin Drive' (PW web). Lycett's effort 
includes the seamy side of the poet, his personal relations with his wife Caitlin Thomas, his character and reputation; and it is a 'candid revisiting of the familiar one' (ibid.). John Goodby in 2013 wrote The Poetry of Dylan Thomas: Under the Spelling Wall which is one of the latest attempt for modern theoretical approaches to Dylan Thomas: the reappraisal includes critical survey through the parameters of such theories, as - modernism, the body, gender, the carnivalesque, language, hybridity, performance and the pastoral (amazon review web). The volume shows unprecedented enthusiasm for the avant-gardism of Thomas and modernizes the critical filed in reading Thomas' poetry.

Due to Dylan Thomas's inconsistent life style, and sometimes extremely 'ill-balanced' (qtd. in PF web) poetical ventures, his works often suffered harsher treatment: Henry Treece quotes some reputable critic who considered Thomas beside Eliot and Auden - 'dog among the fairies' [title of the volume - Dylan Thomas: 'Dog among the Fairies' (1948), (PF web)]; or that of being labeled as an 'intellectual fakes of the highest class' (ibid.). But that is hardly consensual; unanimity rests on Thomas being one of the finest lyric masters of the modernists. Ralph Maud claims that 'And death shall have no dominion' is Thomas' first published poem, which encountered immense and immediate popularity. But his first poetical volume 18 Poems (1934) failed to draw much attention. An original sensibility and evolving of style from the earlier manuscripts verses are discernible. Morning Post reviewed the poems as 'individual but not private' (qtd. in ibid.). But Paul Ferris shows that there were certain positive reviews as well. Constantine Fitzgibbon who produced the first, compact biography - The Life of Dylan Thomas (1965) is of the opinion that from the very beginning his excessive drinking, philandering, asocial behavior produced the impression of 'the romantic artist at odds with the modern world' (PF web). Critics are generally impressed by Thomas' obsession with word-play, rhythm, unnatural syntax and revolutionary images. William Tindall, Clark Emery and many such critics were struck by the difficulty of his first poetic volume and attempted to provide comprehensive meaning. Elder Olson, however, finds [The Poetry of Dylan Thomas (1954)] such merits in Dylan Thomas's poetry, as the unity of time, the interplay of creative-destructive forces and the holistic unity of all living beings. At the time of the publication of Twenty-Five Poems (1936), which marks greater clarity and craftsmanship, Thomas was in close proximity with some great literary figures, like Herbert Reid, Geoffrey Grigson, Vernon Watkins [who edited Dylan Thomas: Letters to Vernon Watkins (1982)] and others. Dame Edith Sitwell's favorable review for The Sunday Times - that the work 'is on a huge scale, both in theme and structurally' (ibid.) - assured the volume instant success. The volume mostly containing previous notebook poems, attempts at a sonnet sequence, which might have not reached that height; G. S. Fraser thinks that they are mostly dominated by 'feeling rather than thought' (ibid.). Modifying Olson's eulogism who being touched by the poet's symbolism, commented highly of the poems ['among the greatest poems of the century' (ibid.)] Tindall argues that the sonnets operate centering round the poet's own personality, aiming to resolve his own spiritual conflict. Commenting on Thomas' religious beliefs, R. B. Kershnar called him, 'a pagan, a mystic, and a humanistic agonistic' (ibid.) .

Goodby and Wigginton show that although initially reviewed as 'formless' (qtd. in 4) The Map of Love (1939) ultimately acquires friendly reception as 'tightly controlled and shaped' (ibid.). John Fuller treats the poems as Thomas' awakening to 'real grief and love' (PF web). Deaths and Entrances (1946) arguably Thomas' most accomplished work in the opinion of John Ackerman, establishes him as 'the first great civilian war poet' (xv) and also initiates his fascination for 'lyrical pantheism' (ibid.). T. H. Jones also thought of the volume as his most remarkable achievement; Jacob Krog finds in his presentation of the landscape - 'a new solidity, a new self-sufficiency' (PF web). "Fern Hill", "A Refusal to Mourn", "Poem in October" clearly showcase Thomas' sacramental world view and pantheistic creed. W. T. Moynihan, noticing the profound originality of his metrical skill, termed his rhythm as 'accentual syllabic' (qtd. in ibid.). In Country Sleep (1952) only added to Thomas' reputation. R. M. Kidder observed in the volume the poet's confrontation with death; but 'death through a form of worship' (ibid.). Tindall found the poet 'at his mellowest' (ibid.). Collected Poems (1952), mostly comprised of earlier notebook poems evoked 'moralistic critical responses' (Goodby \& Wigginton 4) and as Goodby \& Wigginton argues pictures the poet as 'a poetic peter pan'

\footnotetext{
${ }^{3}$ Hughes, Heaney and Thomas are all modernist poets and had given primary importance to the presentation of nature. But their approaches to nature were different. Hughes followed the tradition of Blake and Lawrence. Heaney followed the Wordsworthian school. But Thomas takes an apollonian stance to nature where his pantheistic belief is closer to Hopkins.
} 
(5). Ralph Maud edited Poet in the Making: the Notebooks of Dylan Thomas (1968) which exemplifies the extraordinary precocity and unique style of the poet. ${ }^{4}$

Among his prose works The Portrait of the Artist as a Young Dog (1940) shows some kind of dubiousness and flippancy. Times Literary Supplement considered it 'smut and practical joke' (PF web). Under Milk Wood (1954) shows Dylan Thomas' remarkable handling of the prose form and distinctively marks him as 'essentially Welsh' (Goodby \& Wigginton 4). Richard Morton finds in it 'a kind of esoteric significance' (PF web). Raymond Williams, however, dismisses it 'as some adolescent's imaginings' (ibid.). Thomas' radio broadcast and films scripts also received energetic reception. Yet his is a case of too often resulting in mixed, often unfavorable - not so illuminating critical exposition. Seamus Heaney in one of his Oxford lectures mentioned Dylan Thomas the poet as a 'case history' (wiki web). David Holbrook found him as destructive of his own 'true voice' (ibid.). But in reality, although he differs from the normal stature of canonical writers, there are several scholars and critics who readily acknowledge his championing mastery over rhyme and lyrical forms: Robert Lowell finds him great in his 'dazzling obscure(ity)' (ibid.); Kenneth Rexroth discovered in his poetry 'reeling excitement and intoxica(tion)' (ibid.); Philip Larkin acknowledged - "none can 'stick words into us like pins' . . . like he can" (ibid.); Neil Corcoran finds merits even enough in Thomas' novel form 'for a contemporary Bakhtinian reassessment' (Goodby \& Wigginton 3); James A. Davies defended 'taking Thomas seriously' (9); John Ackerman concludes the discussion of Thomas' poetry in the Volume A Dylan Thomas Companion: Life, Poetry and Prose with quoting Dame Edith Sitwell who commented: he 'is a poet through whom Nature speaks' (162). ${ }^{5}$

Several other critical works ranging from institutional criticism to recent theoretical approaches on Dylan Thomas show that his works are not undone by reductive 'critical deadlock' (Goodby \& WIgginton 4). The followings are some of the few that promote comprehensive critical discourse on the poet: J. M. Brinnin edited A Case Book on Dylan Thomas (1960), Clark Emery's The World of Dylan Thomas (1971), Constantine Fitzgibbon's The Life of Dylan Thomas (1965), Dylan Thomas (1965) by Jacob Korg, E. W. Tedlock's Dylan Thomas: the Legend and the Poet (1960), James A. Davies' three volumes - Dylan Thomas' Places: a Biographical and Literary Guide (1987), A Reference Companion to Dylan Thomas (1998), and A Pocket Guide to Dylan Thomas' Swansea, Gower and Laugharne (2000), R. B. Kershner, Jr.'s Dylan Thomas: the Poet and his Critics (1976), Andrew Sinclair's Dylan Thomas: Poet of His People (1975) and Dylan the Bard (1999), David N. Thomas' Dylan Thomas Remembered (vol. I-II) (2003-4) and Fatal Neglect: Who Killed Dylan Thomas (2008) etc. Certain journals, like - Welsh Journals, Dylan Thomas in America, An Intimate Journal, Southwest Journal and some well maintained websites, such as - the Poetry Foundation Website (www.poetryfoundation.org), the official website on the poet (www.dylanthomas.com), that of the Dylan Thomas Society (www.dylanthomassocietyofgb.co.uk) are constantly producing progressive ideas on different aspects of Thomas' poetry.

\section{REFERENCES}

[1] Ackerman, John. A Dylan Thomas Companion: Life, Poetry and Prose. Basingstoke: Macmillan, 1991. Print.

[2] Allen, Michael. Seamus Heaney: New Case Books. New York: Palgrave Macmillan, 1997. “Amazon Book Review”. Amazon. http://www.amazon.co.uk/The-Poetry-Dylan-Thomas Liverpool/dp/ 1846318769. Web. Accessed on 24.07.2013, at 9 pm.

[3] Andrews, Elmer Kennedy- (ed.). The Poetry of Seamus Heaney. Great Britain: Palgrave Macmillan, 1998. Print.

[4] Armbruster, Karla \& Kathleen R. Wallace (eds.). Beyond Nature Writing: Expanding the Boundaries of Ecocriticism.: USA UP of Virginia, 2001. Print.

[5] Barry, Peter. Beginning Theory: An Introduction to Literary and Cultural Theory. Manchester: Manchester U P, 2007. Print.

\footnotetext{
4 Thomas' notebook poems are his earliest ventures into poetry making. Among these poems some are incorporated to his latter volumes and some are gone to obscurity.

${ }^{5}$ The range of criticism on Dylan Thomas varies so widely that it is not possible to inculcate any clear cut view. Yet informed with several counts from the Wikipedia and Poetry Foundation Website on Thomas and form the illuminating book edited by Gooodby and Wigginton, I formulated the general critical reception that Thomas' works enjoyed. Yet I fear that sometimes I have become over simplistic in my approach and I also acknowledge that for the lack of space I often omitted several theoretically oriented observations on Thomas' poetry.
} 
[6] Bate, Jonathan. Romantic Ecology: Wordsworth and the Environmental Tradition. London: Routledge, 1991. Print.

[7] Blake Morrison. http://www.blakemorrison.com/books/sh.htm. Web. accessed on 21.03.2014, at 9pm.

[8] Bloom, Harold (ed.). Seamus Heany. United States of Amrica: Chelsea House Pub., 2003. Print.

[9] Branch, Michael. "Indexing American Possibilities: The National History Writing of Bartram, Wilson and Audobon". The Ecocriticism Reader: Landmarks in Literary Ecology. (eds.) by Cheryll Glotfelty and Harold Fromm. London: U of Georgia Press, 1996. Print.

[10] Buell, Lawrence. The Environmental Imagination: Thoreau, Nature Writing, and the Formation of American Culture. Cambridge: Havard UP, 1995. Print.

[11] - - - - The Future of Environmental Criticism. USA: Blackwell Pub., 2005. Print.

[12] Carson, Rachel. Silent Spring. 1962. America: Penguin Classic, 2000. Print.

[13] Chamberlain, Richard. "Fuse and Refuse: the Pastoral Logic of Dylan Thomas's Poetry". www.dylanthomasboathouse.com. Web. Accessed on 24.04.1013, at 9pm.

[14] Clark, Timothy. The Cambridge Introduction to Literature and the Environment. New York: Cambridge UP, 2011. Print.

[15] Corcoran, Neil. The Poetry of Seamus Heaney: a Critical Study. London: Faber and Faber, 1998. Print.

[16] Coupe, Laurence, ed. The Green Studies Reader: from Romanticism to Ecocriticism. London and New York: Routledge, 2000. Print.

[17] "Dylan Thomas". Poetry Foundation. http://www.poetryfoundation.org/bio/dylan-thomas. Web. Accessed on 24.05.2014, at $9 \mathrm{pm}$. (cited as PF)

[18] “Dylan Thomas". Wikipedia. http://en.wikipedia.org/wiki/Dylan_Thomas. Web. Accessed on 24.02.2012, at $9 \mathrm{pm}$.

[19] "Ecopoetry". Wikipedia. http://en.wikipedia.org/wiki/Ecopoetry. Web. Accessed on 24. 04.2013, at 9 pm.

[20] Fomeshi, Behnam Mirzababazadeh. "Two Green Poets: A Comparative Ecocritical Study of Sepehri and Emerson”. http://puslit2.petra.ac.id/ejournal/index.php/ing/article/view/18915. Web. Accessed on 24. O3. 2011, at $9 \mathrm{pm}$.

[21] Fromm, Harold. "From Transcendence to Obsolescence". The Ecocriticism Reader: Landmarks in Literary Ecology. (eds.) by Cheryll Glotfelty and Harold Fromm. London: U of Georgia Press, 1996. Print.

[22] Garrard, Greg. Ecocriticism: the New Critical Idiom. London: Routledge, 2004. Print.

[23] Gifford, Terry. Ted Hughes. London \& New York: Routledge, 2009. Print.

[24] - - - . Pastoral. London: Routledge, 1999. Print.

[25] - - - "The Social Construction of Nature". The Green Studies Reader: from Romanticism to Ecocriticism. (ed.) by Laurence Coupe. London and New York: Routledge, 2000. Print.

[26] Gifford, Terry, and Neil Roberts. Ted Hughes: a Critical Study. London: Faber and Faber, 1981. Print.

[27] Glotfelty, Cheryll. "Introduction: Literary Studies in an Age of Environmental Crisis". The Ecocriticism Reader: Landmarks in Literary Ecology. (eds.) by Cheryll Glotfelty and Harold Fromm. London: U of Georgia Press, 1996. Print.

[28] Glotfelty, Cheryll, and Harold Fromm (eds.). The Ecocriticism Reader: Landmarks in Literary Ecology. London: U of Georgia Press, 1996. Print.

[29] Goodby, John \& Christopher Wigginton (eds.). Dylan Thomas: Contemporary Critical Essays. UK: Palgrave Macmillan, 2001. Print.

[30] Good Reads. https://www.goodreads.com/. Web. Accessed on 24. 06.2012, at 9 pm.

[31] Hart, Henry. Seamus Heaney: Poet of contrary Progressions. New York: Syracuse University Press, 1993. Print.

[32] Hirschberg, Stuart. Myth in the Poetry of Ted Hughes. Country Dublin: Wolfhound Press, 1981. Print.

[33] Holbrook, David. The Code of Night. UK: Athlone Press, 1972. Print.

[34] Howarth, William. "Some Principles of Ecocriticism". The Ecocriticism Reader: Landmarks in Literary Ecology. (eds.) by Cheryll Glotfelty and Harold Fromm. London: U of Georgia Press, 1996. Print.

[35] Huggan, Graham \& Helen Tiffin. Postcolonial Ecocriticism. USA \& Canada: Routledge, 2010. Print.

[36] Hutchings, Kevin. "Ecocriticism in British Romantic studies". Literature Compass. www.onlinelibrary .wiley.com/doi/10.1111/j.1741-4113.2008.00529.x/pdf. web. accessed on 24. 06.2013, at 9 pm.

[37] "Introduction to Ecocriticism". ASLE. http://www.asle.org/site/resources/ecocritical-library/intro/. Web. Accessed on 24.05.2014, at 9 pm.

[38] Keith Sagar: Litarary Critic and Poet. http://www.keithsagar.co.uk/. Web. Accessed on 15.05.2013, at 9 pm. 
[39] Kerridge, Richard. "Ecological Hardy". Beyond Nature Wring: Expanding the Boundaries of Ecocriticism. (eds.) Karla Armbruster \& Kathleen R. Wallace. USA UP of Virginia, 2001. Print.

[40] Llewellyn, Richard. How Green Was My Valley (1939). England: Penguin Books Ltd., 2001. Print.

[41] Lyon, Thomas J. "A Taxonomy of Nature Writing”. The Ecocriticism Reader: Landmarks in Literary Ecology. (eds.) by Cheryll Glotfelty and Harold Fromm. London: U of Georgia Press, 1996. Print.

[42] Maud, Ralph. Where have the Old Words Got me. Cardiff: U of Wales P, 2003. Print.

[43] Nayar, Pramod K. Contemporary Literary and cultural Theory: from Structuralism to Ecocriticism. India: Dorling Kindersley Pvt. Ltd., 2010. Print.

[44] O’Donoghue, Bernard. The Cambridge Companion to Seamus Heaney. UK: Cambridge UP, 2008. Print.

[45] Parker, Michael. Seamus Heaney: the Making of a Poet. Iowa City: Univ. of Iowa Press, 1993. Print.

[46] Perkins, David. A History of Modern Poetry (Vol. 2). USA: Belknap Press of Harvard UP, 1987. Print.

[47] Persee. http://www.persee.fr/web/revues/home/prescript/article/rbph_00350818_1986_num_64_3_5607_t1_0661_0000_2. Web. Accessed on 14.04. 2014, at 9 pm.

[48] Philip, Dana. “Is Nature Necessary?”. The Ecocriticism Reader: Landmarks in Literary Ecology. (eds.) by Cheryll Glotfelty and Harold Fromm. London: U of Georgia Press, 1996. Print.

[49] "Poetry of Resistance". http://ohioswallow.com/book/The+Poetry+of+Resistance. Web. Accessed on 24.03.2009, at 9 pm. Print.

[50] "Ralph Waldo Emerson". The Basis of Philosophy. http://www.philosophybasics.com/philosophers _emerson.html. web.accessed on 18.12.2012, at 9 pm.

[51] Rigby, Kate. "Ecocriticism". www.asle.org/assets/docs/ECOCRITICISM+Rigby+article.pdf.Web. Access ed on 24.05.2014, at 9 pm.

[52] Rueckert, William. "Literature and Ecology: An Experiment in Ecocriticism". The Ecocriticism Reader: Landmarks in Literary Ecology. (eds.) by Cheryll Glotfelty and Harold Fromm. London: U of Georgia Press, 1996. Print.

[53] Ruskin, John. "Landscape, Mimesis and Morality". The Green Studies Reader: from Romanticism to Ecocriticism. (ed.) by Laurence Coupe. London and New York: Routledge, 2000. Print.

[54] Sagar, Keith. The Art of Ted Hughes. London: Cambridge U P, 1978. Print.

[55] - - - -. Ted Hughes. London: Longman, 1972. Print.

[56] Scheese, Don. "Desert Solitaire: Counter-Friction to the Machine in the Garden". The Ecocriticism Reader: Landmarks in Literary Ecology. (eds.) by Cheryll Glotfelty and Harold Fromm. London: U of Georgia Press, 1996. Print.

[57] Scigaj, Leonard M. "Ted Hughes and Ecology: a Biocentric Vision”. The Challenge of Ted Hughes. (ed.) by Keith M. Sagar. London: Palgrave Macmillan, 1994. Print.

[58] "Seamus Heaney". Poetry Foundation. http://www.poetryfoundation.org/bio/seamus-heaney. Web. Accessed on 18.05.20114, at 9 pm.

[59] "Seamus Heaney". Wikipedia. http://en.wikipedia.org/wiki/Seamus_Heaney. Web. Accessed on 24. 05.2014, at 9 pm. (Cited as PF)

[60] Slovic, Scott. "Nature Writing and Environmental Psychology: The Interiority of Outdoor Experience". The Ecocriticism Reader: Landmarks in Literary Ecology. (eds.) by Cheryll Glotfelty and Harold Fromm. London: U of Georgia Press, 1996. Print.

[61] - - - "Ecocriticism: Containing Multitudes, Practising Doctrine". The Green Studies Reader: from Romanticism to Ecocriticism. (ed.) by Laurence Coupe. London and New York: Routledge, 2000. Print.

[62] Soans, Catherine \& Angus Stevenson (eds.). Oxford Dictionary of English (2nd ed.). New York: OUP, 2006. Print.

[63] Soper, Kate. "The Idea of Nature”. The Green Studies Reader: from Romanticism to Ecocriticism. (ed.) by Laurence Coupe. London and New York: Routledge, 2000. Print.

[64] Speek, Tiiu. "Environment in Literature: Lawrence Buell's Ecocritical Perspective”. www.eki.ee/km/place /pdf/KP1_18speek.pdf. Web. Accessed on 15. Web. Accessed on 15.05.2014, at 9 pm.

[65] Tan, Joan Qionglin. Han Shan, Chan Buddhism and Gary Snyder's Ecopoetic Way. Great Britain: Sussex Academy Press, 2009. Print.

[66] Thoreau, Henry D. Walden. London: Dent, 1992. Print.

[67] Turner, Frederick. "Cultivating the American Garden". The Ecocriticism Reader: Landmarks in Literary Ecology. (eds.) by Cheryll Glotfelty and Harold Fromm. London: U of Georgia Press, 1996. Print.

[68] UGA Press. http://www.ugapress.org/index.php/books/dylan_thomas. Web. Accessed on 21.10.2113, 9 pm.

[69] Waugh, Patricia. Literary Theory and Criticism. London: Oxford U P, 2006. Print. 
[70] White Jr., Lynn. "The Historical Roots of Our Ecologic Crisis". The Ecocriticism Reader: Landmarks in Literary Ecology. (eds.) by Cheryll Glotfelty and Harold Fromm. London: U of Georgia Press, 1996. Print.

[71] Williams, Raymond. "The Green Language". The Green Studies Reader: from Romanticism to Ecocriticism. (ed.) by Laurence Coupe. London and New York: Routledge, 2000. Print.

Citation: Arindam Ghosh. "Survey of Literature: Ted Hughes, Seamus Heaney and Dylan Thomas" International Journal on Studies in English Language and Literature (IJSELL), vol 6, no.9, 2018, pp. 17-29. doi:http://dx.doi.org/10.20431/2347-3134.0609003.

Copyright: (C) 2018 Authors. This is an open-access article distributed under the terms of the Creative Commons Attribution License, which permits unrestricted use, distribution, and reproduction in any medium, provided the original author and source are credited. 